\title{
Analisis Dramatistic Pentad pada Film Crazy Rich Asians (2018) sebagai Antitesis Pandangan Orientalisme
}

\author{
Rossi Amelia Christy ${ }^{1}$, Taufan Teguh Akbari ${ }^{2}$, dan Muhammad Fajar Satriya ${ }^{3}$ \\ Institut Komunikasi dan Bisnis London School of Public Relations, Jakarta, Indonesia
}

\begin{abstract}
ABSTRAK
Penelitian ini berfokus pada film Crazy Rich Asians (2018) sebagai representasi antitesis akan konsep orientalisme yang dikritik oleh Edward Said. Metode penelitian yang digunakan adalah metode kualitatif dengan teknik analisis dramatistik pentad dari Kenneth Burke. Melalui penelitian ini disimpulkan bahwa bangsa Asia mampu merepresentasikan dirinya dalam perfilman Barat. Melalui film sebagai industri media yang efektif untuk menyebarkan pesan bahwa Singapura bukanlah bangsa yang terbelakang, biadab, eksotis, dan berbahaya serta adanya benturan kebudayaan antara Barat (occident) dan Asia (orient).
\end{abstract}

\begin{abstract}
This research focus is on Crazy Rich Asians (2018) movie's as the anti-thesis of orientalism's concept criticized by Edward Said. This research uses qualitative method and Dramatistic Pentad analysis techniques from Kenneth Burke. This research concludes that the Asia is able to represent itself in the western cinema industry. The film became an effective communication media to spread the messages that Singapore is not as backward, barbaric, exotic and dangerous also the intercultural issues between the West (occident) and Asia (orient).
\end{abstract}

KATA KUNCI

Orientalisme, Edward Said, Crazy Rich Asians (2018), Dramatistic Pentad, Media Komunikasi

\section{KEYWORDS} Orientalism, Edward Said, Crazy Rich Asians (2018), Dramatistic Pentad, Communication Media

\section{PENDAHULUAN}

Film merupakan bentuk komunikasi masa visual yang paling dominan diseluruh dunia, lebih dari seratus juta orang setiap minggunya menonton film di bioskop, ditelevisi, maupun dvd (Agee, Ault, Emery, 1997, p.369). Film lahir dari perkembangan fotografi dan gambar bergerak. Film menjadi media masa yang tidak hanya sekedar hiburan, namun juga menjadi alat transmisi gagasan yang dapat menembus hambatan bahasa dan wilayah. Setelah akhir perang dunia ke II, perkembangan pasar film Hollywood meluas ke seluruh dunia (Agee, Ault, Emery, 1997, p.369). 
Paramount, Disney, Warner Brothers, Twentieth Century Fox, Universal dan Sony (Columbia) adalah perusahaan - perusahaan yang berasosiasi dengan Hollywood dalam bisnis perfilman sebagai yang paling dikenal dan terkuat sejak awal abad ke 21, namun tidak semua film dimana nama mereka dicantumkan adalah murni produksinya, sering kali film diproduksikan oleh perusahaan lain dan mereka hanyalah sebagai distributor film (Turow, 2009, p.477). Saat ini film Hollywood tidak hanya dapat ditonton melalui layar bioskop saja, seiring dengan kemajuan teknologi saat ini film dapat juga disaksikan melalui internet.

Ide dalam membuat sebuah film bisa datang darimana saja, namun plot cerita dalam film umumnya ditulis oleh seorang penulis script dan ide yang diadaptasi dari sebuah buku. Sejak akhir tahun 1990an ide film yang datang dari buku-buku menjadi sangat popular, produser akan mencari buku - buku sukses dengan cerita yang sesuai dengan jenis dan anggaran film yang diharapkan akan akan dibuat (Turow, 2009, p. 479).

Film Crazy Rich Asian adalah film bergenre komedi romantis yang dirilis pada 15 Agustus 2018 diproduksi oleh Warner Bros dan disutradarai oleh John M. Chu (Now You See Me 2). Film ini diadaptasi dari bagian pertama novel trilogi karya Kevin Kwan pada tahun 2013 yang mendapat penghargaan sebagai international Best Seller dari New York Times, bagian kedua berjudul China Rich Girlfriend (2013) dan bagian ketiga berjudul Rich People Proble (2017). Film dengan latar belakang kebudayaan Asia khususnya Singapura, berhasil dan sukses menempatkan film ini masuk kedalam 10 besar Box Office Amerika dengan budget US $\$ 30.000 .000$ (estimasi) dan meraih keuntungan kurang lebih US $\$ 165,634,563$ pada 30 September 2018 (IMDB, 2018) serta mendapatkan rating 91\% dalam situs review film Rotten Tomatoes.

Kesuksesan film ini masuk menjadi nomor satu di chart box office film internasional sejak 24 Agustus 2018 hingga minggu ke tiga (6 Oktober 2018) menghasilkan pendapatan \$38.918.441 dan telah diputar di 3,526 teater didunia (Numbers, 2018). Tentunya melalui film ini membawa harapan dapat memperluas representasi Asia di film Amerika Serikat. Melalui film ini juga memperjelas kebangkitan kekayaan di Asia dan meningkatnya visibilitas orang Asia di dunia Barat.

Dalam artikel New York Times (2018), film ini memberikan kekuatan keberagaman budaya, dengan menunjukan kebudayaan Asia yang kuat, destinasi di Asia yang menarik untuk dikunjungi, serta makanan tradisional khas Asia. Dalam artikel Time yang diterbitkan pada tanggal 15 Agustus 2018 "Crazy Rich Asians is Going to Change Hollywood" film ini merupakan kisah modern pertama setelah 25 tahun terakhir dengan semua pemeran utama adalah orang Asia dan Asia-Amerika, setelah The Joy Luck Club (1993) yang diproduksi oleh Disney. Dengan merepresentasikan orang-orang Asia secara jelas, film ini bisa dijadikan contoh kesuksesan bagi industri film di Asia. Karena selama beberapa dekade, orang Asia-Amerika yang bekerja di industri film dan televisi telah menanggung beban berat yang hampir tidak mungkin untuk bisa menghapus sistem yang 
cenderung menghukum, stereotip dan mengabaikan Asia. Sungguh sangat berlawanan dengan penggambaran Asia yang digambarkan Hollywood sebelumnya, di film ini secara jelas terlihat Asia telah bertumbuh menjadi kawasan yang terlihat sangat kaya, glamor, modern dan mempesona.

Film Crazy Rich Asians (2018) bercerita menengai kisah seorang gadis bernama Rachel Chu (Constance $\mathrm{Wu}$ ) seorang gadis keturunan Cina yang lahir di Amerika dan dibesarkan oleh ibunya yang merupakan imigran asal Cina. Berprofesi sebagai professor ekonomi di New York yang kemudian bersama kekasihnya Nick Young (Henry Golding) melakukan perjalanan ke Singapura. Ini merupakan perjalanan pertama Rachel Chu ke Asia dengan tujuan untuk menghadiri pernikahan sahabat Nick dan sekaligus juga untuk bertemu dengan keluarga besar Nick di Singapura. Sesampainya di Singapura Rachel terkejut karena selama ini dia tidak tahu bahwa Nick berasal dari salah satu keturunan keluarga yang terpandang dan sangat kaya raya di Singapura, status sosial keluarga Nick pun sangat berbeda dengan dirinya. Menjadi kekasih Nick membuat Rachel yang hanya seorang rakyat biasa berada ditengah kalangan elite, sehingga menjadi target kecemburuan para sosialita muda yang ingin mendapatkan perhatian Nick, selain itu konflik antara Rachel dengan ibunda Nick, Eleanor (Michelle Yeoh) yang berusaha untuk memisahkan hubungan keduanya karena Rachel dianggap tidak cocok dengan nilai - nilai di Asia. Film ini memperlihatkan perbedaan nilai antara Barat dan Timur.

Film dihasilkan dari berbagai belahan dunia, dari Barat salah satunya adalah industri film Hollywood Amerika Serikat. Film yang berasal dari Timur beberapa diantaranya adalah industri film Bollywood dari India, Cina, Jepang, dan Korea. Hollywood sangat berperan penting bagi citra Amerika Serikat dihadapan publik internasional, disamping itu juga merupakan alat representasi kultural yang menunjukan cara pandang Amerika (Barat) terhadap budaya lain diluar dirinya atau other (Haeri, 2016)

"The essence of Orientalism is the ineradicable distinction between western superiority and Oriental inferiority" (Said, 2003, p.42)

Edward Said dalam bukunya Orientalisme menyatakan adanya dikotomi antara Barat dan Timur. Negara Barat digambarkan sebagai negara yang maju, kuat, pandai berbicara, superior. Sedangkan negara Timur dipandang sebagai yang belum berkembang, lemah, misterius dan inferior.

Dalam hubungan internasional, orientalisme tidak dapat lepas dari praktik kebudayaan dalam menginterpretasikan, menjelaskan dan memahami aspek Ras, Kelas, dan Gender yang menggambarkan citra dikotomi antara Timur dan Barat melalui film. Peran film dalam mengkonstruksikan realitas suatu bangsa dapat mempengaruhi persepsi masyarakat internasional dan pola-pola interaksi dalam hubungan internasional, sehingga studi hubungan internasional tidak bisa mengesampingkan peran media internasional, termasuk film dalam memproduksi nilai-nilai Asia (Timur) yang pada akhirnya menciptakan suatu realitas. Realitas inilah yang kemudian menghasilkan 
munculnya beberapa teori Barat pada pola - pola interaksi dalam hubungan internasional seperti Dependecy-interdependency Theory, East-West Countries, FirstThird World Country yang terkonstruksi oleh struktur korporasi orientalisme yang disebarkan melalui media - media internasional (Sujawonto, 2012).

Pemaparan latar belakang ini menjadi titik awal untuk memahami bagaimana film dengan latar belakang kebudayaan Asia menjadi antitesis terhadap pandangan orientalisme yang dapat mempengaruhi citra suatu bangsa di dunia internasional. Tujuan dari penelitian ini adalah untuk mengintrepretasikan, memahami dan menyingkap pesan-pesan antitesis terhadap orientalisme yang ada dalam film Crazy Rich Asians (2018).

Pada awal abad ke 19 hingga akhir perang dunia ke-2 dominasi kekuatan Perancis dan Inggris telah menguasai Orientalisme dan 'the orient' yang menunjukan bahwa kekuatan besar hanya berasal dari 'the Occident' (Perancis, Inggris atau Amerika) (Said, 2003, p.4). The Orient (Timur) adalah sebuah gagasan, ide, imajinasi atau ciptaan Barat yang bukan berdasarkan realitas sebenarnya atas budaya, etnis, bahasa, masyarakat, dan geografisnya. Tujuan orientalist adalah untuk membentuk dan menguatkan identitas Barat yang lebih unggul dibandingkan Timur dengan merepresentasikan budaya, sejarah, dan politik melawan Timur. Orientalisme merupakan bentuk kontrol Barat terhadap Timur.

Dituliskan dalam bukunya Orientalism (2003) Said merupakan seorang professor bahasa inggris dan sastra di universitas Colombia pada tahun 1991. Said menentang gagasan orientalisme dalam bukunya Orientalism (2003), yang menyatakan bahwa orientalisme adalah merupakan cara pandang dan persepsi Barat (the west) yang salah mengenai budaya dan orang-orang di negara Timur seperti Timur Tengah, Asia dan Afrika Utara (orient).

Edward Said dalam bukunya Orientalism (2003, p.2):

"Anyone who teaches, write about, or research the Orient and this applies whether the person is an anthropologiest, sociologist, historian, or philologist either in its specific or its general aspects, in an orientalist, and what he or she does is Orientalism"

Menurut Edward Said, ada tiga istilah dalam orientalisme. Pertama, Orient yang menunjukan wilayah dan bangsa yanga ada di Timur. Kedua, Orientalis yang berarti para ahli yaitu antropolog, sosiolog, sejarahwan, dan ahli bahasa yang melakukan penelitian, menulis dan mempelajari tentang Timur. Ketiga, Orientalisme yang merujuk pada hasil pemikiran yang berupa ideologi atau paham tentang Timur.

Edward Said (2003, p.45) menyatakan bahwa yang menjadi masalah utama dalam Orientalisme adalah terbaginya realitas manusia kedalam budaya, sejarah, tradisi, 
masyarakat bahkan ras yang membedakan antara Barat dan Timur, karena teori, praktik, dan nilai-nilai orientalist yang ditemukan oleh Barat, sehingga mengukuhkan hegemoni Barat terhadap Timur yang dianggap sebagai suatu kebenaran ilmiah. Tujuan orientalist adalah untuk membentuk dan menguatkan identitas Barat yang lebih unggul dibandingkan Timur dengan merepresentasikan budaya, sejarah, dan politik melawan Timur. Orientalisme merupakan bentuk kontrol Barat terhadap Timur. Menurut Said Orientalisme menawarkan kita bukan gambaran sesungguhnya dari Timur tetapi representasi, presentasi ulang, rekonstruksi, yang pada dasarnya merupakan pengetahuan penjajah, yang diciptakan oleh penjajah untuk memahami yang dijajah, dan dirancang untuk menegaskan identitas, meningkatkan hegemoni politik dan budaya khas Barat atas bangsa Asia (Clarke, 2003, p.22). Sehingga dapat dikatakan orientalisme tidak dirancang untuk orang Asia dan tidak menggambarkan kenyataan yang sesungguhnya.

Menurut Yang (2011) media Barat memiliki persepsi yang dominan mengenai orang Asia dan budaya Asia dibandingkan dengan penggambaran secara realistis. Representasi Asia oleh barat terutama Asia Timur sebagian besar berisikan stereotipe negatif. Imajinasi para orientalis Barat telah mendominasi penggambaran tempat, masyarakat dan budaya di Timur termasuk Asia.

Kim \& Chung (2005) menyatakan film pertama Amerika yang mendukung gagasan orientalisme adalah film The Bitter Tea of General Yen (1993) dan film Dr. Fu Manchu, citra orang-orang Asia yang lemah dan aseksual hidup berdampingan dengan citra orangorang Timur sebagai binatang buas yang mengancam akan merusak stabilitas ekonomi dan moral bangsa AS dan keluarga Amerika. Representasi budaya semacam itu yang kemudian mendorong kemunduran ideologi untuk semangat anti-Cina, yang menyebabkan pecahnya kerusuhan anti-Cina dan mendorong pelaksanaan First Chinese Exclusion Act pada tahun 1882. First Chinese Exclusion Act adalah hukum pertama Amerika yang melarang imigran asal Cina masuk ke Amerika.

Budaya merupakan identitas suatu negara agar dapat dikenal oleh masyarakat internasional. Film yang menggambarkan konsep Orientalisme dapat merusak persepsi, citra, nilai dan kebudayaan dari suatu negara. Karena tidak digambarkan berdasarkan realitas. Film animasi Mulan yang diproduksi oleh Disney pada tahun 1998, merupakan gambaran figure sosok pahlawan perempuan dari Cina. Latar tempat dalam fillm Mulan berada di Cina dengan menggambarkan tembok Cina, namun kostum Mulan dengan Kimono, bunga sakura bukan berasal Cina, tetapi Jepang. Ini merupan representasi budaya yang salah dan dapat merusak budaya di Asia, karena Cina dan Jepang memiliki kebudayaan yang berbeda.

Pada awal tahun 1990an, banyak orang Amerika memandang Asia sebagai tempat yang tidak hanya disisi dunia lain, tetapi juga mewakili segala sesuatu yang berlawanan dengan cara hidup Amerika. Asia dilihat sebagai wilayah yang dipenuhi dengan petani bekerja keras di desa-desa dan prajurit misterius terlibat dalam petualangan romantis, 
berbeda dengan Amerika Serikat, di mana orang bekerja di pabrik dan menikmati kegiatan rekreasi modern (John \& Mable, n.d, p.4).

Sebagai salat satu alat representasi budaya, Hollywood menghasilkan beragam film yang menunjukan cara pandang Amerika (Barat) terhadap budaya lain diluar dirinya. Dalam imajinasi Barat, Timur sering dianggap sebagai warna - warni dan memikat yang dirangkum dalam kata eksotis, atau sebaliknya sebagai yang menyeramakan dan mengancam seperti yellow peril, gerombolan asiatik, despotisme timur (Clarke, 2003, p.4). Dalam berbagai film yang diproduksi oleh Hollywood Barat selalu digambarkan sebagai sosok pahlawan bagi Timur, sedangkan Timur merupakan kaum yang lemah, bodoh dan menunggu Barat untuk menyelamatkannya. Timur seringkali digambarkan sebagai tempat yang menyeramkankan, dipenuhi dengan orang bar-bar, tidak beradab sehingga nilai-nilai Barat lah yang dibutuhkan dan bisa untuk menyelesaikan masalah yang ada dinegara-negara Timur.

Dalam film The Pirates of Caribbean: At The World's End (2007) citra negatif Cina yang serakah ditampilkan dalam sosok Sao Feng penguasa bajak laut Singapura. Memoir of a Geisha (2005) film yang diadaptasi dari buku karya Arthur Golden dengan judul yang sama pada tahun 1997 dan disutradarai oleh Rob Marshall. Buku autobiografi Mineko Iwasaki (Geisha, A Life) yang diterbikan di 22 negara hanya terjual sebanyak 500.000 salinan sedangkan Memoirs of Geisha sebanyak empat juta salinan (Hanwald,2000; Shoji,2005).

Film Memoirs of Geisha menghadirkan Timur sebagai objek Barat yang dikomodifikasi dengan fiksi yang dibuat oleh Barat dan untuk Barat yang diterima sebagai sebuah kenyataan dengan menjadikan Jepang dan budaya Geisha sebagai objek seksualitas, eksotis dan romantis (Akita, 2006). Transformer 4: Age of Extinction (2014) di Cina, terlihat kawasan perumahan yang kumuh, kotor,sempit dan sekelompok orang yang tidak berbahasa inggris. Doctor Strange (2016) yang diproduksi oleh Marvel dimana salah satu latar tempat berada di Kathmandu, Nepal. Merepresentasikan Asia dengan pemandangan kuil-kuil, biksu serta pengobatan alternative dengan metode kepercayaan yang tentunya bertolak belakang dengan Barat yang hanya mempercayai ilmu pengetahuan dan dokter dalam bidang kesehatan.

Menurut Keith (dalam Haeri, 2016) ada sepuluh stereotip mengenai orang Asia dalam industri Hollywood yang hadir dalam 452 film dan acara TV dari tahun 1919 hingga 2016: Perpetual foreign; Martial arts; Model minority; Nerd/geek; Gendered racism; Inferior \& subordinate; Mystic; Arc villain, dragon lady / yellow peril; Caricature, Yellow face bizarre / unfathomable; Willing / deserving targets of open denigration

Namun saat ini penggambaran akan Asia dimedia mulai bergeser dari penggambaran sebagai musuh yang kejam, primitive, eksotis, licik, berbahaya dan biadab. Banyaknya film dan stasiun TV memberikan penghormatan dan toleransi kepada Asia dengan 
memberikan peran dominan kepada orang Asia, makanan Asia yang dikonsumsi oleh Barat, dan tempat - tempat di Asia yang menarik untuk dikunjungi seperti dalam film Crazy Rich Asians. Budaya merupakan identitas suatu negara, lewat budaya suatu negara dapat dikenal oleh publik internasional.

\section{METODOLOGI PENELITIAN / METHOD}

Dramatistic Pentad adalah metode yang dikembangkan oleh Burke (1954) setelah teori dramatisme untuk memahami aktivitas simbolik, yang terdiri atas lima point analisis yang mencakup tindakan (act), adegan (scene), agen (agent), agensi (agency), dan tujuan (purpose) (Blakesley, 2001, p.8): Tindakan (act) - Apa yang dilakukan? Menunjukan tindakan yang dilakukan oleh tokoh. Contohnya dalam film Crazy Rich Asians (2018) adalah tokoh Rachel Chu, Nick Young, Eleanor Young dan tokoh lainnya.; Adegan (scene) - Kapan tindakan dilakukan? Merupakan konteks yang melingkupi tindakan.; Agen (agent) - Siapa yang melakukan tindakan? Adalah orang-orang yang melakukan tindakan.; Agensi (agency) - Bagaimana Agen melakukan tindakan? Mengacu pada caracara yang digunakan oleh agen dalam melakukan tindakan, seperti strategi pesan, kisah yang diceritakan pidato dan permintaan maaf.

Dalam film Crazy Rich Asians, agency dilihat dalam cara Rachel Chu menarik hati Eleanor Young yang merupakan ibu dari Nick kekasihnya untuk menyukai dirinya. Tujuan (purpose) - Mengapa tindakan tersebut dilakukan? Mengacu pada tujuan yang ingin dicapai agen dalam melakukan tindakan tersebut. Dalam film Crazy Rich Asians tujuan Rachel Chu dan Nick pergi ke Singapura untuk bertemu keluarga Nick. Dalam adegan lain tokoh Eleanor Young, sebagai seorang ibu yang menentang hubungan Nick dan Rachel karena status sosial Rachel.

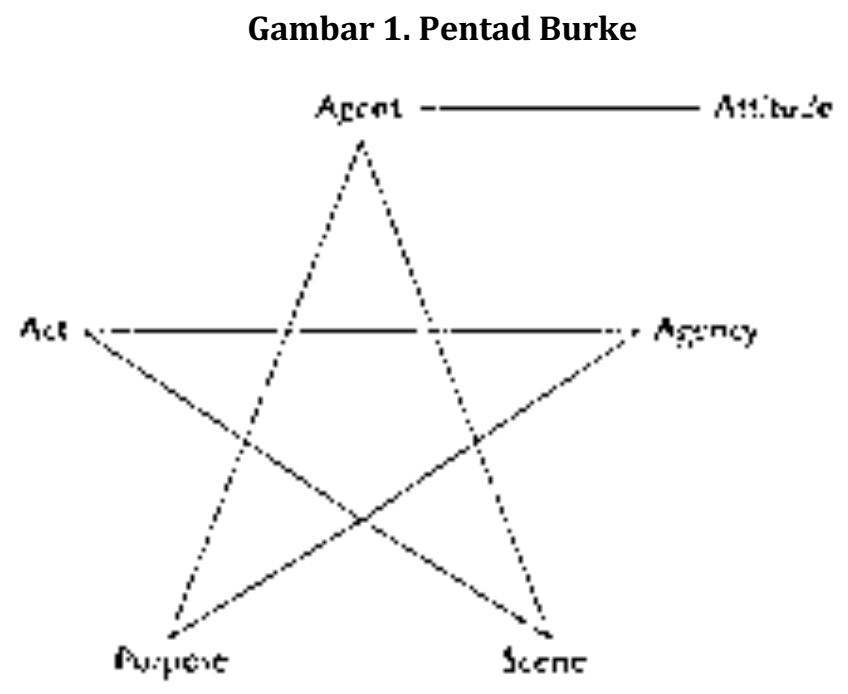

Sumber: West \& Turner (2008, p.34) 
Tabel 1. Dramatistic Pentad

\begin{tabular}{lllll}
\hline Act & Scene & Agent & Agency & Purpose \\
\hline Response & Situation & Subject & Stimulus & Target \\
\hline
\end{tabular}

Sumber: Griffin, Ledbetter, \& Sparks (2015, p. 295)

\section{HASIL DAN PEMBAHASAN / RESULT AND DISCUSSION}

\section{Sinopsis Film Crazy Rich Asians}

Film Crazy Rich Asian mengisahkan tentang kisah seorang gadis bernama Rachel Chu (Constance $\mathrm{Wu}$ ) gadis keturunan Asia yang lahir di Amerika, dibesarkan oleh ibunya seorang imigran asal Cina dan tumbuh dengan nilai-nilai Amerika. Berprofesi sebagai professor ekonomi di New York yang kemudian bersama kekasihnya Nick Young (Henry Goulding) melakukan perjalanan ke kampung halaman Nick di Singapura. Ini merupakan kunjungan pertama Rachel ke Asia, tujuan kepergian mereka adalah untuk menghadiri pernikahan sahabat Nick dan sekaligus juga untuk bertemu dengan keluarga Nick. Sesampainya di Singapura Rachel terkejut karena selama ini tidak mengetahui bahwa Nick berasal dari salah satu keturunan keluarga yang terpandang dan sangat kaya raya di Singapura, status sosial keluarga Nick pun sangat berbeda dengan dirinya. Menjadi kekasih Nick membuat Rachel yang hanya seorang rakyat biasa berada ditengah kalangan elite, sehingga menjadi target kecemburuan para sosialita muda yang ingin mendapatkan perhatian Nick, selain itu konflik antara Rachel dengan ibunda Nick, Eleanor (Michelle Yeoh) yang berusaha untuk memisahkan hubungan keduanya karena Rachel dianggap sangat Amerika yang tidak cocok dengan budaya dan nilai-nilai di Asia.

Berdasarkan tujuan penelitian ini yaitu untuk melihat film Crazy Rich Asians (2018) sebagai antitesis Orientalisme, dengan menggunakan analisis Dramatistic Pentad, dalam 10 adegan yang diteliti menghasilkan gagasan sebagai berikut: Stereotipe Barat dalam memposisikan dirinya sebagai bangsa yang superior sehingga memandang rendah orang-orang Timur dan mendiskriminasi ras, dalam film ini adalah ras Cina Singapura. Sehingga keluarga Elenaor Young harus melakukan sesuatu yang besar yang dapat membuat orang Barat menghargai dan mengakui keberadaan mereka. Penggambaran ini terdapat pada scene 1.; Multikultur terhadap keturunan Cina yaitu keturunan Cina Singapura, keturunan Cina-Amerika dan keturunan Cina daratan (mainland). Hal ini tergambar dalam scene 2 , scene 5 , scene 6 scene 7 yang menggambarkan perbedaan bahasa, perilaku ekonomi dan budaya.; Secara geografis letak Singapura dan Cina sangatlah jauh. Mayoritas penduduk Singapura adalah keturunan Cina, ini tergambar dari percakapan dalam scene 6 antara Peik Lin dan Rachel Chu. Keturunan Cina-Amerika adalah bangsa minoritas di Amerika, yang seringkali diabaikan dan mendapatkan penolakan seperti rasisme dan stereotipe negative seperti dalam adegan discene 1 ketika Eleanor Young dan keluarganya mendapatkan perlakuan buruk dari staffs hotel di London.; Dalam film ini bangsa Barat tidak digambarkan lebih superior dari orang-orang Asia, khususnya di Singapura seperti yang terlihat pada gambar 21 dalam scene 8. 
Berkebalikan dengan pandangan orientalisme yang memandang Barat sebagai bangsa yang superior dibandingkan dengan bangsa Timur. ; Film Crazy Rich Asians (2018) memperlihatkan kemewahan, modernitas dan kekayaan yang luar biasa dari kalangan ultrarich Cina Singapura. Dalam scene 7 dan scene 8 dimana kalangan ultrarich Singapura sangat suka mengadakan pesta mewah yang mengundang seluruh kalangan sosial atas. Film ini juga menjelaskan mengenai perbedaan pandangan hidup dan perilaku ekonomi mereka, yaitu antara new money dan old money. ; Rachel Chu merepresentasikan keturunan Cina Amerika sebagai minoritas yang tumbuh dan besar dengan nilai-nilai barat seperti kebebasan dan kesetaraan, seperti yang tergambar dalam scene 3 dan 10 dimana Rachel Chu merasa tidak ada perbedaan dengan keluarga Nick Young di Singapura. Ketika Rachel Chu berada diantara kalangan elite kaya raya tidak membuat dirinya segan dan rendah diri berada di sekeliling mereka.; Film Crazy Rich Asians menceritakan mengenai bagaimana suatu nilai-nilai kebudayaan yang dihormati dan yang tentunya ini berlawanan dengan pandangan orientalisme mengenai bangsa Timur yang tidak beradab, terbelakang, misterius dan berbahaya. Hal ini tergambar dalam gambar 30 dalam scene 9, adegan keluarga Nick Young duduk bersama membuat dumplings makanan tradisional khas cina.; Film Crazy Rich Asians memberikan pesan bahwa perbedaan pandangan antara Eleanor Young yang merepresentasikan pandangan Timur dan Rachel Chu yang mewakili pemikiran Barat sebagai suatu hal yang harus dipelajari, didengar dan dimengerti oleh kedua belah pihak bukan sebagai masalah atau permusuhan yang patut disingkirkan dalam pandangan Orientalisme.

Film Crazy Rich Asians adalah wadah untuk mengenal moral, multikulturalisme dan kebudayaan terhadap keturunan Cina Singapura berdasarkan dengan pandangan bangsa Timur. Konsep Orientalisme dari Edward Said telah menjadi suatu konsep yang sangat menarik untuk menganalisis dan menjelaskan suatu tempat dibelahan dunia yang disebut orient. Secara tradisional, bagaimana individu berusaha untuk mengerti dan memahami bagian dari area geografis dan wilayah telah dibentuk oleh positivism dan empiricism, yang mengarah pada asumsi objektif dan kebenaran universal mengenai suatu tempat yang dapat diungkapkan dan dijelaskan secara akurat (Leong, 2011). Kemampuan orientalisme untuk membingkai suatu asumsi dengan cara mengungkapkan relasi antara kekuatan dan pengetahuan, antara subjek pengamat dan yang lebih kuat dan objek bawahan yang lemah (Leong, 2011).

The orient is not passive, lissible object waiting to be represented, but was imaginatevely created and willed out to observer's preconceived fantasies, anxieties, and stereotypes of these place (Said, 2003, P. 5-6).

Seperti yang dituliskan oleh Said, orient bukanlah objek pasif yang menunggu untuk diwakili, tetapi secara imajinatif diciptakan dan diarahkan kepada fantasi, kecemasan dan stereotipe dari pengamat (barat) yang telah terbentuk mengenai Timur.

Menurut Leong dalam jurnalnya yang berjudul Singapore, Southeast Asia and Other Place of Orientalism (2011) menuliskan ada beberapa hal yang membuat mengapa 
penggambaran akan orient tidak berdasarkan apa yang sesungguhnya terjadi. Pertama, ketika yang memproduksi suatu pengetahuan menganggap dirinya lebih berkuasa dari objek yang dia amati, maka objek yang diamati akan digambarkan lebih rendah dari dirinya. Kedua, posisi biner yang melekat antara Barat sebagai "knowing self' dan Oriental sebagai 'knowing others'. Edward Said dalam wawancara yang berjudul On Orientalism mengemukakan pandangannya mengenai orientalisme yang digambarkan oleh barat dalam beragam media, orient adalah tempat misterius yang penuh dengan stereotipe seperti wanita yang sensual, misterius, monster, dan mistis (Jhally, 2005).

Film Crazy Rich Asians adalah film yang diproduksi dan diperankan oleh orang-orang Asia. Setelah lebih dari 25 tahun sejak film The Joy Luck Club yang diproduksi oleh Disney pada tahun 1993, dengan seluruh pemerannya adalah orang Asia. Hollywood telah cukup lama membungkam representasi orang-orang Asia dalam industry film. Kevin Kwan yang merupakan penulis dari novel Crazy Rich Asian mengatakan dalam wawancaranya dengan Milken Institute:

I wanted to take a framework of looking a family of extremely wealth and really telling the story of what's happening in Asia now. You know the fact that over the last century it has risen to become the region of the most powerful economic... (Milken Institute, 2018)

Pernyataan Kevin Kwan ini didukung oleh data sebagai berikut:

Gambar 2. Perkembangan Jumlah Miliarder Lintas Subregional Tahun 2016-2017

\begin{tabular}{|c|c|c|c|c|c|c|}
\hline Region & Subregion & $\begin{array}{r}\text { Number of } \\
\text { billionaires } 2016\end{array}$ & $\begin{array}{r}\text { Number of } \\
\text { billionaires } 2017\end{array}$ & $\begin{array}{l}\text { Avg. wealth } \\
2017 \text { in USDm }\end{array}$ & Avg. age 2017 & $\begin{array}{l}\text { Share of female } \\
\text { billionaires in \% }\end{array}$ \\
\hline \multirow[t]{4}{*}{ APAC } & & 711 & 814 & $3,328.6$ & 61.43 & $8 \%$ \\
\hline & Greater China & 418 & 475 & $3,240.4$ & 55.75 & $8 \%$ \\
\hline & Oceania & 34 & 43 & $2,741.9$ & 66.07 & $23 \%$ \\
\hline & South East Asia & 259 & 296 & $3,555.4$ & 66.71 & $4 \%$ \\
\hline \multirow[t]{4}{*}{ EMEA } & & 586 & 629 & $4,108.1$ & 62.23 & $13 \%$ \\
\hline & Eastern Europe & 147 & 163 & $3,366.3$ & 56.88 & $4 \%$ \\
\hline & MENA & 42 & 52 & $3,175.0$ & 63.94 & $6 \%$ \\
\hline & Western Europe & 397 & 414 & $4,517.4$ & 64.11 & $18 \%$ \\
\hline \multirow[t]{3}{*}{ Americas } & & 682 & 715 & $5,078.7$ & 66.99 & $12 \%$ \\
\hline & $\begin{array}{l}\text { Central and } \\
\text { South America }\end{array}$ & 83 & 84 & $4,596.4$ & 68.71 & $14 \%$ \\
\hline & North America & 599 & 631 & $5,142.9$ & 66.76 & $12 \%$ \\
\hline Total & & 1979 & 2158 & $4,135.7$ & 63.51 & $11 \%$ \\
\hline
\end{tabular}

Sumber: UBS \& PWC Billionaires (2017)

Hal ini menunujkan adanya global shifting power yaitu peralihan kekuatan perekonomian dunia yang saat ini terpusat di Asia dan dipegang oleh Cina di peringkat pertama dengan 
pertumbuhan sebesar 14\% dua kali lipat dibandungkan Eropa yang hanya mengalami kenaikan 7\% dan tiga kali lipat tingkat kenaikan Amerika yang hanya mencapai 5\% (UBS \& PWC, 2017, p.13).

Berikut adalah kutipan pernyataan dari wawancara Kevin Kwan yang merupakan penulis novel Crazy Rich Asians dengan Milken Institute:

I went to the Time magazine gala at Lincoln Center last week. You know there were all these people on the red carpet Nicole Kidman, JLo, you know past presidents things like that and I'm escorted to the red carpet with Michelle Yeoh, and the PR lady with the clipboard in the headset looks at awesome cheese she goes "mr. Kwan congratulations nice to meet you, is this your wife?" and I just went oh, no no no no no. I mean she's you know literally probably the most famous woman in Asia, Michelle yeah Michelle. And the fact that these women did not know who she was here in New York working in PR it just shows to you. You know how much we need a movie like this

Berdasarkan pernyataan Kevin Kwan diatas peneliti berpendapat bahwa bangsa Timur hanyalah sebagai objek dan konsumen dari apa yang dihasilkan oleh bangsa Barat. Artis Hollywood dikenal oleh masyarakat dihampir seluruh belahan dunia, tetapi sebaliknya artis yang sangat terkenal di Asia belum tentu dikenali oleh masyarakat yang ada di Barat. Hal ini menegaskan bahwa Barat belum menjadi konsumen dari produk budaya Asia.

Sepanjang film ini kita dapat menyaksikan kemewahan dan kekayaan dari orang-orang Asia yang cantik, berkelas dan menawan. Keberhasilan Crazy Rich Asians (2018) meraup keuntungan sebesar US\$ 165 juta (dengan anggaran US\$ 30 juta) pada September 2018 (IMBD, 2018) menjadikannya sebagai film komedi romantis keenam paling sukses sepanjang masa sebagai film pertama yang berpusat pada karakter Asia yaitu Cina Singapura dan Cina Amerika, setelah film the Joy Luck Club (1993) dengan semua pemeran utamanya adalah orang-orang Asia. Hal ini tentunya menunjukan bahwa film Crazy Rich Asians berhasil menarik penonton secara global dengan menceritakan mengenai pengaruh kekuatan ekonomi dan kebudayaan yang besar di Asia Tenggara yaitu keturunan cina yang ada di Singapura. Hal ini tentunya merupakan kesuksesan bagi orang-orang Asia untuk melihat dirinya dapat direpresentasikan dalam industri film Hollywood. Berdasarkan hasil riset dari USC Anneberg School for Communication and Journalism menemukan bahwa diantara 800 film paling popular dari tahun 2007 hingga 2015 hanya 4,8\% peran yang dimainkan oleh orang Asia dan Asia-Amerika dan hanya sebesar 2.8\% disutradarai oleh orang Asia maupun Asia-Amerika (Le \& Kang, 2019).

Riset yang dikeluarkan oleh Hollywood Diversity pada tahun 2017 yang dilakukan oleh UCLA African American Studies Departement menemukan bahwa sepanjang tahun 20142015, orang Asia-Amerika hanya memerankan 5\% dari 806 peran dalam acara TV, 3\% dari 1,141 peran dalam acara TV kabel dan hanya 7\% dari 301 peran dalam pertunjukan digital (Le \& Kang, 2019). Artikel majalan Time 2016 menuliskan bahwa hanya 19\% direktur acara TV dan 13\% penulis acara TV adalah ras minoritas (Le \& Kang, 2019). 
Ketika Orang Asia dan Asia-Amerika digambarkan seringkali representasi tersebut mereproduksi stereotipe orientalist tentang wanita Asia yang eksotis, patuh, hiperseksual, dan pria Asia sebagai ahli kung fu, monster yang berbahaya, kutu buku, canggung secara sosial dan tidak maskulin. Jika stereotipe negative mengenai orangorang Asia ini terus berlanjut dalam industry film Hollywood bukan tidak mungkin, audiences akan membenci suatu kebudayaan tertentu karena dianggap berbahaya.

Film ini berfokus pada gaya hidup mewah, kaya dan berkuasa dari kalangan ultrarich di Singapura, hal inilah yang disambut sebagai perubahan yang baik karena orang Cina sering kali digambarkan sebagai orang asing dan dipinggirkan karena dianggap berbahaya. Namun film Crazy Rich Asians (2018) tidak dapat digunakan untuk mewakili representasi seluruh orang Asia dalam mengungkap identitas dan kebudayaaan Asia khususnya semua keturunan Cina atau imigran asal Cina, film ini hanya gambaran dari satu irisan mengenai Asia.

Dalam film ini juga terlihat adanya pertentangan antara budaya barat dan timur yang awalnya menimbulkan permusuhan antara Eleanor Young yang mewakili pandangan Timur, yaitu keturunan Cina Singapura dan Rachel Chu yang mewakili pandangan Barat sebagai keturunan Cina Amerika. Kesalahan terminologi sebutan "orang cina” sering kali diberikan kepada orang-orang berkulit putih dan memiliki mata yang sipit dan bisa berbahasa mandarin oleh berbagai media-media Barat, khususnya dalam film-film yang dibuat oleh Hollywood. Ada tiga jenis orang Cina yang digambarkan melalui film Crazy Rich Asians (2018) oleh Kevin Kwan, mengenai perbedaan antara etnis Cina daratan (yang tinggal di RRC) dan etnis Cina yang tinggal diluar Republic Rakyat Cina (RRC). Tiga jenis penggambaran mengenai orang Cina dalam film Crazy Rich Asians (2018) adalah: keturunan Cina Amerika; keturunan Cina Singapura; keturunan Cina Daratan

Berdasarkan pengalaman pribadi Kevin Kwan sebagai keturunan Cina Singapura yang tinggal di Barat, memberikan gambaran mengenai perbedaan sosio-kultural diantara kelompok-kelompok etnis Cina. Film Crazy Rich Asians (2018) menampilkan cara berbusana, perilaku ekonomi dan pesta-pesta yang dibuat oleh kalangan elit Cina Singapura yang dipengaruhi oleh latar belakang pendidikan, sosio-kultural dan budaya dimana orang-orang Cina ini tinggal dan menetap yaitu di Singapura. Keturunan Cina di Singapura adalah etnis mayoritas dengan populasi penduduk sebanyak 74\%. Dalam film ini keluarga Nick Young digambarkan sebagai keturunan Cina Singapura yang masuk dalam kategori old money.

Kevin Kwan dalam artikel Daily News tahun 2013 (Connelly, 2013) mengatakan mengenai perbedaan pola ekonomi antara New Money dan Old Money. New Money lebih suka membelanjakan dan memamerkan kekayaan yang mereka miliki dengan membeli barang-barang high brand, sedangkan Old Money adalah kekayaan dinasti yang dibuat oleh keluarga perantauan Cina yang membangun kekayaan yang luar biasa hingga 30 
generasi, dan mereka lebih suka untuk menyembunyikan hal yang mereka miliki (Connelly, 2013).

Berdasarkan pernyataan Kevin Kwan ini, peneliti berpendapat bahwa kepribadian Nick Young saat tinggal di New York yang terlihat sederhana dan cenderung menutupi kekayaan yang dimiliki oleh keluarganya di Singapura adalah representasi dirinya sebagai Old Money. Bahkan kekasihnya Rachel Chu tidak menyangka bahwa Nick dan Keluarganya adalah orang yang sangat kaya raya di Singapura dan memiliki bisnis dibeberapa negara di Asia.

Film ini tidak dapat digunakan untuk mengeneralisasi semua perilaku keturunan Cina Singapura dan keturunan Cina Daratan (mainland) dan keturunan Cina Amerika maupun keturunan Cina di negara lain, karena realitas dan pandangan hidup mereka dipengaruhi oleh budaya dan politik dimana imigran Cina ini menetap disuatu negara. Rachel Chu yang mewakili pandangan keturunan Cina Amerika yang memiliki keyakinan terhadap nilai-nilai kebarat -baratan yaitu egalitarianisme. Rachel Chu mengganggap bahwa dirinya sederajat dan memiliki kesempatan yang sama dengan siapapun. Karena itu dia tidak merasa berbeda dengan keturunan Cina Singapura, bahkan ketika dia telah mengetahui kekayaan keluarga Nick tidak membuat dia merasa memiliki masalah dengan status sosial ekonominya dan merasa sangat percaya diri untuk dapat diterima dengan baik oleh keluarga Young.

Peneliti berharap penelitian ini dapat memberikan referensi baru dalam memandang keturunan Cina dan mencegah perilaku rasisme dalam memandang budaya lain yang berbeda dengan kita, tanpa menempatkan diri kita sebagai bangsa yang superior dan budaya lain tidak beradab.

Berdasarkan dari pembahasan diatas peneliti menemukan fakta - fakta yang terkait dengan anti-tesis orientalisme yang menunjukan perbedaan pandangan antara Barat dan Timur seperti dalam tabel dibawah ini:

Tabel 2. Anti-tesis Orientalisme

\begin{tabular}{lllll}
\hline No & $\begin{array}{l}\text { Padangan } \\
\text { Barat } \\
\text { Singapura }\end{array}$ & $\begin{array}{r}\text { Orientalisme } \\
\text { Terhadap }\end{array}$ & $\begin{array}{l}\text { Anti-tesis orientalisme dalam film Crazy } \\
\text { Rich Asians (2018) }\end{array}$ \\
\hline 1 & $\begin{array}{l}\text { Bangsa Timur tidak bisa } \\
\text { berbahasa Inggris dengan } \\
\text { baik }\end{array}$ & Film Crazy Rich Asians & (2018) \\
& Singapura adalah orang yang pandai, \\
& berkelas, dan memiliki kemampuan \\
& berbahasa inggris yang baik. & \\
& & Singlish bukanlah bahasa inggris yang rusak, \\
& ini merupakan identitas budaya Singapura. \\
& & Singlish adalah logatlokal bahasa inggris yang \\
& & dicampur dengan bahasa Cina dan Melayu \\
\hline
\end{tabular}




\begin{tabular}{|c|c|c|}
\hline & & $\begin{array}{l}\text { yang bertujuan untuk memfasilitasi interaksi } \\
\text { antar ras dan golongan di Singapura. }\end{array}$ \\
\hline \multirow[t]{2}{*}{2} & $\begin{array}{l}\text { Bangsa Timur merupakan } \\
\text { bangsa yang terbelakang } \\
\text { dan tidak modern }\end{array}$ & $\begin{array}{l}\text { Meskipun keturunan Cina Singapura dalam } \\
\text { film Crazy Rich Asians (2018) digambarkan } \\
\text { sebagai kalangan ultrarich Singapura yang } \\
\text { hidup dengan kemewahan dan modern, } \\
\text { namun }\end{array}$ \\
\hline & & $\begin{array}{l}\text { keturunan Cina Singapura tetap } \\
\text { mempertahankan identitas budaya mereka } \\
\text { sebagai orang Cina. }\end{array}$ \\
\hline 3 & $\begin{array}{l}\text { Bangsa Timur adalah } \\
\text { bangsa yang bar-bar, } \\
\text { misterius, mistis dan } \\
\text { eksotis }\end{array}$ & $\begin{array}{l}\text { Dalam film Crazy Rich Asians (2018) } \\
\text { menceritakan mengenai gaya hidup, } \\
\text { pandangan dan nilai budaya dari keturunan } \\
\text { Cina Singapura dan keturunan Cina Amerika, } \\
\text { yaitu bukan sebagai bangsa yang misterius, } \\
\text { mistis dan bar-bar. }\end{array}$ \\
\hline 4 & $\begin{array}{l}\text { Bangsa Barat adalah } \\
\text { bangsa yang superior } \\
\text { dibandingkan dengan } \\
\text { Timur }\end{array}$ & $\begin{array}{l}\text { Dalam film Crazy Rich Asians (2018) bangsa } \\
\text { Barat bukanlah bangsa yang superior di } \\
\text { Singapura. }\end{array}$ \\
\hline
\end{tabular}

Sumber: Data Olahan Peneliti (2019)

Crazy Rich Asians (2018) merupakan film dengan sudut pandang yang baru dengan melihat Asia dari sisi lain, khususnya Asia Tenggara yang termasuk negara dunia ketiga yang sering dipandang sebagai negara berkembang yang terbelakang, miskin, lemah dan misterius. Dalam film Crazy Rich Asians banyak mengambil latar tempat di Singapura, tempat yang mungkin tidak dikenal oleh sebagian orang Barat. Mayoritas penduduk di Singapura 74.3\% adalah Cina, Melayu 13,4\%, India 9,0\% dan etnis lainnya 3.2\% (Department of Statistics Singapore, 2018). Singapura merupakan salah satu negara dikawasan Asia Tenggara yang minim sumber daya alam, dengan latar belakang masyarakat multi-ras yang hidup secara harmoni menjadikan Singapura sebagai lingkungan yang aman dan stabil secara politik dan ekonomi (Yee, 2009). Dalam film ini banyak menggambarkan mengenai tradisi kebudayaan Cina karena mayoritas penduduk di Singapura adalah imigran asal Cina. Namun bukan hanya Cina tetapi dalam beberapa scene ras Melayu dan India juga diperlihatkan dalam beberapa adegan dalam film.

Dalam film komedi klasik Road To Singapore (1940) menggambarkan Singapura pada saat itu sebagai desa nelayan penuh perahu. Dalam Crazy Rich Asians (2018) Singapura telah berubah menjadi negara metropolis glamor yang dipenuhi dengan orang-orang kaya. Kevin Kwan dalam wawancaranya dengan Milken Institute (Milken Institute, 2018) mengatakan "I wanted to take a look of looking at a family of extremely wealth and telling 
the story of what's happening in Asia now, you know the fact that over the last century it has risen to become the region of the most powerful economic"

Pernyataan Kevin Kwan kemudian diperkuat dengan data dari UBS \& PWC (2017) yang menunjukan bahwa Asia berada di peringkat pertama dengan jumlah 637 miliarder di Asia, diurutan kedua A.S dengan 563 miliarder dan Eropa diperingkat ketiga dengan 342 miliarder.

\section{Gambar 3. Peningkatan Kekayaan Asia, Eropa, dan Amerika}

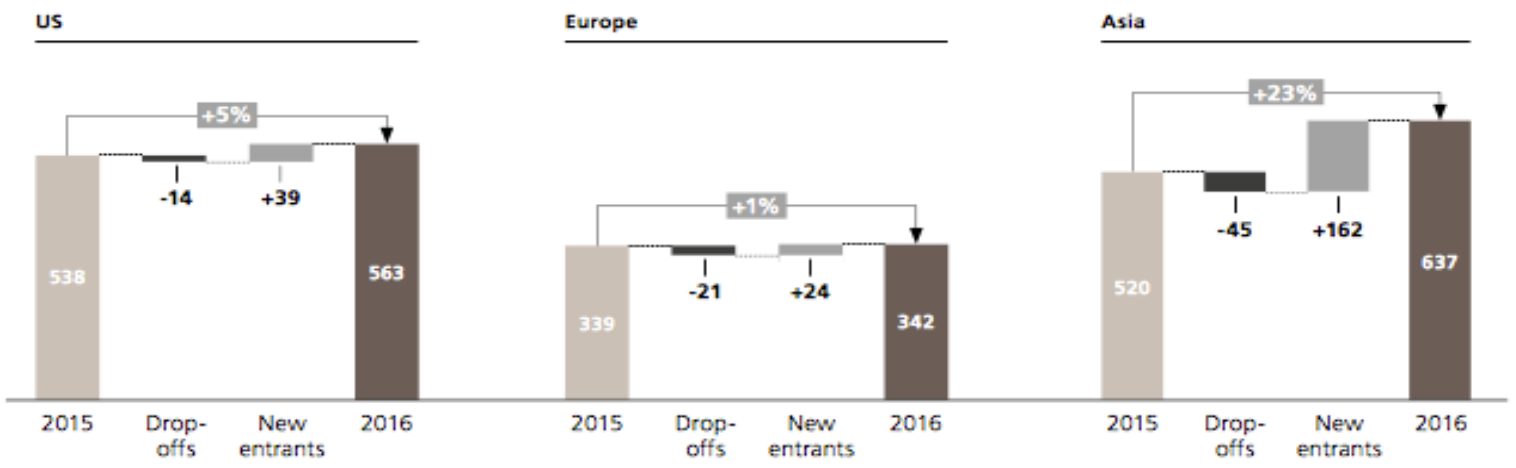

Sumber: UBS \& PwC Billionaires Insight (2017)

Rogoff (2018) adalah seorang profesor ekonomi dan kebijakan publik di Harvard University dalam tulisannya yang dimuat dalam Project Syndicate menyatakan "With an unexpected hit on its hands, perhaps Hollywood will use more films like "Crazy Rich Asians" to illustrate key concepts about a region that is the biggest economic success story of the last several decades. There are many more stories about that story to be told" (Crazy Rich Asia, 2018).

\section{SIMPULAN / CONCLUSION}

Berdasarkan hasil dari analisis film Crazy Rich Asians (2018) dan konsep Orientalisme dari Edward Said, dalam 10 adegan ini dapat memberikan pandangan mengenai antitesis orientalisme. Anti-tesis orientalisme adalah cara pandang untuk mensejajarkan, mempelajari, membuka diri mengenai pandangan bangsa Timur yang selama ini hanya berisikan pandangan stereotipe negatif oleh bangsa Barat sebagai bangsa yang bar-bar, eksotis, mistis dan misterius yang dikenal dengan pandangan orientalisme.

Film Crazy Rich Asians (2018) hadir dengan seluruh pemerannya adalah orang Asia setelah hampir 25 tahun sejak film The Joy Luck Club (1993) dalam industri perfilman Hollywood sangat minim akan representasi orang-orang Asia. Ini adalah wujud dari bagaimana kita menghargai suatu perbedaan ras serta kebudayaan dan tidak memandang bangsa lain dengan pandangan rasisme. Perbedaan tidak seharusnya 
melegalkan klaim atas ras, bangsa, negara dan budaya sebagai pihak yang superior dan lainnya adalah inferior sehingga menimbulkan permusuhan. Selama ini superioritas Barat melalui industri film Hollywood hanya berisi fantasi yang bisa merusak representasi orang-orang Asia dengan memiliki persepsi yang dominan dibandingkan dengan penggambaran secara realistis.

\section{DAFTAR PUSTAKA}

Agee, W.K., Edwin, Ault, P.H., Emery, E.(1997). Introduction to Mass Communications Theory (12 ${ }^{\text {th }}$ edition). New York: Longman.

Akita, K. (2006). Orientalism and the Binary of Fact and Fiction in Memoirs of Geisha. Global Media Journal, 5(9), 1-11.

Billionaires Insight 2017: New Value Creators Gain Momentum. (2017). Retrieved September 22, 2018 from Website PWC: https://www.pwc.com/gx/en/financialservices/Billionaires\%20insights/billionaires-insights-2017.pdf

Blakesley, D. (2001). The Elements of Dramatism. Richmond: Longman.

Clarke, J.J. (2003). Oriental Enlightenment: The Encounter Between Asian and Western Thought. New York: Routledge.

Griffin, E., Ledbetter, A., Sparks, G. (2015). A First Look at Communication Theory (9th edition). New York: McGraw-Hill Education.

Haeri, I. Z (2016). Wanita Asia Dalam Imajinasi Digital: Kajian Literature Atas Orientalism. Jurnal Kajian Wilayah, 7(2), 129-143.

IMDB. (n.d) Crazy Rich Asians (2018), Diperoleh 30 September from Website IMDB: https://www.rottentomatoes.com/m/crazy rich asians/

Jhally, S, (2012). Edward Said on Orientalism. Retrieved Oktober 20, 2018 from Youtube: https://www.youtube.com/watch?v=fVC8EYd Z g\&t=1334s

Kim, M., Chung, A.Y. (2005). Consuming Orientalism: image of Asian/ American women in multicultural advertising. Qualitative Sociology 28(1), 67-91.

Milken Institute. (2018, Juli 9). A Conversation With "Crazy Rich Asian” Author Kevin Kwan (File Video). Retrieved September 20, 2018 from Youtube https://www.youtube.com/watch?v=k26Q1XI6Rpk\&t=506s

Rotten Tomatoes. (n.d) Crazy Rich Asians (2018). Retrived September 30, 2018 from Website Rotten

Tomatoes:

https://www.rottentomatoes.com/m/crazy rich asians/

Said, E.W (2003). Orientalism. Lodon: Penguin Books,Ltd.

Sujawonto, F. A. (2012). Citra Indonesia di Dunia Internasional Melalui Fotografi: Kajian 
Kritis Atas Orientalisme Hubungan Internasional. 2(2), 118-141. Retrived from http://download.garuda.ristekdikti.go.id/article.php?article=97483\&val=261\&ti tle=CITRA\%20INDONESIA\%20DI\%20DUNIA\%20INTERNASIONAL\%20MELALU I\%20FOTOGRAFI:\%20KAIIAN\%20KRITIS\%20ATAS\%200RIENTALISME\%20HU BUNGAN\%20INTERNASIONAL

Turow, J. (2009). Media Today: An Introduction to Mass Communication (3 ${ }^{\text {rd }}$ edition). New York: Routledge.

West, T., Turner, L.H. (2008). Teori Komunikasi Analisis dan Aplikasi, (3 $3^{\text {rd }}$ edition). Jakarta Salemba Humanika.

Yang, Y. (2011). Stereotypes of Asians and Asian Americans in the U.S. Media: Appearance, Disappearance, and Assimilation. Diperoleh dari https://www.google.com/url?sa=t\&rct=j\&q=\&esrc=s\&source=web\&cd=1\&ved= 2ahUKEwj80 H lsLeAhWLso8KHVWkARIQFjAAegQICRAC\&url=https\%3A\%2F\% 2Fbaylor-

ir.tdl.org\%2Fbitstream\%2Fhandle\%2F2104\%2F8249\%2FYueqin Yang masters. pdf\%3Fsequence\%3D1\&usg=AOvVaw3i7K5N9jxdfjiVOG2e0oNe 